\title{
PROFIL KETERAMPILAN MENYUSUN SKENARIO PEMBELAJARAN MAHASISWA CALON GURU BIOLOGI PERGURUAN TINGGI KEAGAMAAN
}

\author{
Ummi Nur Afinni Dwi Jayanti¹ (ummiafinni@uinsu.ac.id) \\ Miza Nina Adlini 1 \\ Khairuna ${ }^{1}$ \\ ${ }^{1}$ Program Studi Tadris Biologi Universitas Islam Negeri Sumatera Utara
}

\begin{abstract}
ABSTRAK
Salah satu keterampilan dasar mengajar yang harus dimiliki seorang guru yaitu keterampilan menyusun skenario pembelajaran. Keterampilan ini mencakup bagaimana guru terampil dalam menyusun tahapan kegiatan pembelajaran, pemilihan media dan instrumen pembelajaran serta alokasi waktu untuk memfasilitasi peserta didik dalam belajar. Penelitian ini bertujuan untuk megetahui tingkat keterampilan mahasiswa calon guru biologi yang menempuh perkuliahan di perguruan tinggi keagamaan dalam menyusun skenario pembelajaran biologi. Subjek penelitian merupakan 18 mahasiswa Program Studi Pendidikan Biologi yang sedang menempuh semester akhir. Sampel diambil melalui metode purposive sampling dengan kriteria mahasiswa tersebut telah menempuh mata kuliah Microteaching dan PPL. Instrumen penelitian yaitu angket penilaian Rencana Perencanaan Pembelajaran. Hasil analisis data menunjukkan mahasiswa masih kurang terampil dalam menyusun skenario pembelajaran biologi. Hasil dari penelitian ini dapat dijadikan sebagai salah satu informasi bagi calon guru khususnya guru biologi untuk meningkatkan keterampilannya dalam menyusun skenario pembelajaran. Selain itu, dosen pengampu mata kuliah perencanaan pembelajaran dan microteaching dapat menjadikan hasil penelitian ini sebagai salah satu tolak ukur untuk merancang kegiatan perkuliahan yang mampu memfasilitasi perkembangan keterampilan mahasiswa calon guru biologi dalam menyusun skenario pembelajaran.
\end{abstract}

Kata Kunci : microteaching, kompetensi guru, profesi guru , perencanaan pembelajaran

\begin{abstract}
One of the essential teaching skills that a teacher must possess is the skill of developing learning scenarios. These skills include the teacher's ability to arrange the stages of learning activities, the selection of media and learning instruments, and the allocation of time to facilitate learners' learning. This study aims to determine the skills of prospective biology teacher students taking lectures in tertiary religious institutions to develop biology learning scenarios. The research subjects were 18 students of Biology Education Study Program who were taking final year. Samples were taken through a purposive sampling method with criteria for the students taking Microteaching and PPL courses. The research instrument was an assessment questionnaire of the Learning Planning Plan. The results of data analysis showed that students were still less skilled in developing biology learning scenarios. The results of this study can be used as information for prospective teachers, especially biology teachers, to improve their skills in developing learning scenarios. Besides, lecturers supporting learning planning and microteaching courses can make the results of this study as one of the benchmarks for designing lecture activities that can help develop the skills of prospective biology teacher students in developing learning scenario $s$.
\end{abstract}

Keywords : microteaching, teacher competency, teacher profession, lesson plan

\section{PENDAHULUAN}

Guru, dalam masyarakat global, diberikan status profesional yang diharapkan untuk melaksanakan pembelajaran yang memfasilitasi perkembangan keterampilan dan sikap yang penting untuk dimiliki siswa (Arends, 2012). Tugas guru tidak hanya berdiri di depan kelas untuk memberikan pemahaman kepada siswa terkait materi tertentu, tetapi harus dapat mengarahkan perkembangan anak didiknya untuk mencapai citacitanya (Suwarna et al., 2013). Hal tersebut dapat dicapai dengan mempersiapkan calon guru yang salah satunya yaitu melalui Lembaga Pendidikan Tenaga Kependidikan (LPTK) sebagai wadah pengembangan keterampilan dasar mengajar seorang guru (Departemen Pendidikan Nasional , 2005). 
Ummi Nur Afinni Dwi Jayanti, Miza Nina Adlini \& Khairuna, Profil Keterampilan Menyusun Skenario Pembelajaran Mahasiswa Calon Guru Biologi Perguruan Tinggi Keagamaan

JURNAL BIOLOKUS Vol.3 (1)

Salah satu komponen keterampilan dasar mengajar yang harus dikuasai guru yaitu keterampilan menyusun skenario pembelajaran (Suwarna, 2013). Keterampilan menyusun skenario pembelajaran merupakan komponen penting yang menunjukkan kepakaran dan profesionalitas guru (Tuinamuana, 2011). Dalam penyusunan skenario pembelajaran, seorang guru harus mampu menguasai secara teoritis unsurunsur yang ada di dalamnya (Simatupang, H dan D. Purnama, 2019). Penelitian Koehler (2015) dan Ruys, Keer \& Aelterman (2012) menunjukkan bahwa sangat penting memberikan kesempatan bagi calon guru untuk mengembangkan kemampuan menyusun skenario pembelajaran sebelum mereka memulai karir sebagai seorang guru. Dengan demikian, saat telah lulus dari pendidikannya, calon guru tersebut memiliki kinerja profesional yang dapat meningkatkan kualitas pendidikan (Jemmi, 2013).

Konsistensi kinerja guru untuk bekerja secara profesional mempunyai keterkaitan dengan kualitas proses pembelajaran (Rohayati, Diana, \& Priyandoko, 2018). Salah satu indikator keberhasilan dari proses pembelajaran yaitu dilihat dari hasil belajar siswa (Vermunt, 2014). Hasil penelitian Frudden (2001); Geijsel et al. (2009); Naafs et.al. (2002); Rockoff (2004); Omoteso, \& Samudara (2011); Stronge, Ward, \& Grant, (2011) \& Stronge, Ward, Tucker \& Hindman (2008) menunjukkan kualitas guru dalam menghasilkan proses pembelajaran memiliki korelasi positif terhadap hasil belajar siswa.

Berhasil atau gagalnya suatu proses pembelajaran dipengaruhi oleh fase perencanaan pembelajaran (Simatupang \& Purnama, 2019; Frudden, 2001; Halpern, 2002; Pinksky, Monson, \& Irby, 1998; Pinksy \& Irby, 1997). Dengan demikian, guru diharapkan dapat membuat perencanaan pembelajaran yang baik sebelum memulai kegiatan belajar mengajar (Rohayati et al., 2018). Walaupun demikian, keadaan saat ini menunjukkan banyak rancangan perencanaan pembelajaran guru yang kurang baik (Safardi, 2009). Hal ini karena guru masih bergantung pada buku teks (Ruys et al., 2012) sementara rencana pembelajaran hanya dianggap sebagai pelengkap (Rohayati et al., 2018).

Penelitian terkait gambaran keterampilan mengajar guru telah banyak dilakukan. Walaupun demikian, penelitian tersebut masih meneliti keterampilan dasar mengajar calon guru Biologi secara umum seperti hasil penelitian (Agustina \& Saputra (2017) dan Lestari (2018) terkait keterampilan dasar mengajar mahasiswa calon guru Biologi pada matakuliah Microteaching serta Luzyawati (2015) terkait keterampilan dasar mengajar guru Biologi. Sementara itu, penelitian yang secara khusus meneliti rancangan pelaksanaan pembelajaran mahasiswa calon guru maupun guru umumnya dilaksanakan pada calon guru Sekolah Dasar (Aufa \& Maizeli, 2014; Gularso, 2017; Hanifa, 2017) dan pada mata pelajaran selain Biologi (Vidiarti, Zulhaini, \& Andrizal, 2019; Wulandari, 2019).

Hasil dari penelitian ini diharapkan dapat memberikan informasi bagi calon guru khususnya pada LPTK perguruan tinggi keagamaan untuk meningkatkan keterampilannya dalam menyusun skenario pembelajaran. Selain itu, informasi dari penelitian ini dapat digunakan oleh dosen pengampu mata kuliah strategi pembelajaran, perencanaan pembelajaran dan microteaching untuk merancang kegiatan perkuliahan yang mampu memfasilitasi perkembangan keterampilan mahasiswa calon guru biologi dalam menyusun skenario pembelajaran. Dengan demikian calon guru lulusan LPTK baik perguruan tinggi umum maupun keagamaan dapat memberikan "best practice" yang efektif dalam pembelajaran.

\section{METODE}

Jenis penelitian yang dilakukan merupakan penelitian deskriptif. Penelitian deksriptif dilakukan untuk mengetahui nilai satu atau lebih variabel tanpa membandingkan dengan variabel lainnya (Sugiyono, 2016). Data yang dipaparkan dalam penelitian ini diperoleh dari hasil analisis penilaian Rencana Pelaksanaan Pembelajaran (RPP) yang dibuat mahasiswa untuk selanjutnya diinterpretasikan.

Penelitian dilakukan di salah satu universitas keagamaan negeri di Kota Medan, Sumatera Utara. Populasi penelitian merupakan mahasiswa Program Studi Pendidikan Biologi semester 8 berjumlah 18 orang. Sampel responden diambil secara purposive sampling. Purposive sampling dilakukan melalui pemilihan sampel yang dianggap dapat menjadi perwakilan dari populasi yang akan diteliti (Gay, L.R.; Geoffrey, E. Mills \& Peter, 2012). Peneliti secara sengaja mengidentifikasi kriteria dalam menentukan sampel. Kriteria penentuan sampel pada penelitian 
Ummi Nur Afinni Dwi Jayanti, Miza Nina Adlini \& Khairuna, Profil Keterampilan Menyusun Skenario Pembelajaran Mahasiswa Calon Guru Biologi Perguruan Tinggi Keagamaan

JURNAL BIOLOKUS Vol.3 (1)

ini yaitu mahasiswa semester yang telah mengambil mata kuliah Magang 2 (Microteaching) dan Magang 3 (PPL di sekolah). Walaupun demikian, karena pemilihan sampel tidak dilakukan secara random, temuan penelitian tidak dapat digeneralisasikan untuk semua mahasiswa calon guru.

Teknik pengumpulan data pada penelitian ini yaitu dengan penilaian RPP mahasiswa yang merupakan hasil produk perkuliahan Microteaching dan PPL di sekolah. Instrumen penelitian yang digunakan yaitu angket penilaian Rencana Pelaksanaan Pembelajaran yang diadaptasi dari Jayanti (2018). Angket penelitian menggunakan skala likert 1-4 dengan kategori skala penilaian sebagai berikut:

Tabel 1. Kategori Skala Penilaian Angket Penilaian RPP.

\begin{tabular}{cl}
\hline Skor & \multicolumn{1}{c}{ Kategori } \\
\hline 1 & $\begin{array}{l}\text { Tidak baik (tidak sesuai, tidak jelas, tidak } \\
\text { tepat guna, tidak operasional }\end{array}$ \\
\hline 2 & $\begin{array}{l}\text { Kurang baik (sesuai, jelas, tidak tepat } \\
\text { guna, tidak operasional) }\end{array}$ \\
\hline 3 & $\begin{array}{l}\text { Baik (sesuai, jelas, tepat guna, kurang } \\
\text { operasional) }\end{array}$ \\
\hline 4 & $\begin{array}{l}\text { Sangat baik (sesuai, jelas, tepat guna, } \\
\text { operasional) }\end{array}$ \\
\hline
\end{tabular}

Sumber: Jayanti (2018)

Aspek yang dinilai pada angket penelitian mencakup: 1) kelengkapan komponen format RPP; 2) kelayakan isi; 3) kesesuaian KD; 4) pemilihan model pembelajaran; 5) perumusan kegiatan pembelajaran; 6) penentuan sumber belajar; 7) penilaian; dan 8) kebahasaan.
Penilaian dilakukan oleh satu orang yaitu peneliti sendiri sebagai dosen matakuliah perencanaan pembelajaran. Hal ini dilakukan agar peneliti mendapatkan diagnosis awal terkait kemampuan menyusun skenario pembelajaran mahasiswa untuk dijadikan refleksi mempersiapkan perkuliahan di semester selanjutnya.

Data yang diperoleh dari angket penilaian RPP diubah menjadi nilai kuantitatif kemudian dianalisis secara deksriptif. Analisis secara deksriptif dilakukan dengan mengkategorikan hasil penilaian dengan kategori seperti yang tercantum pada Tabel 2 .

Tabel 2. Kategori Persentase Keterampilan Menyusun Skenario Mahasiswa

\begin{tabular}{cc}
\hline Rata-rata Nilai & Kategori \\
\hline$<60 \%$ & Kurang \\
\hline $60 \%-70 \%$ & Cukup \\
\hline $71 \%-80 \%$ & Baik \\
\hline$>80 \%$ & Sangat Baik \\
\hline
\end{tabular}

Sumber: Agustina \& Saputra (2017)

\section{HASIL DAN PEMBAHASAN}

\section{Kelengkapan Isi RPP Mahasiswa}

Pengukuran keterampilan menyusun skenario pembelajaran mahasiswa calon guru biologi dilakukan dengan melakukan penilaian kelengkapan komponen RPP.

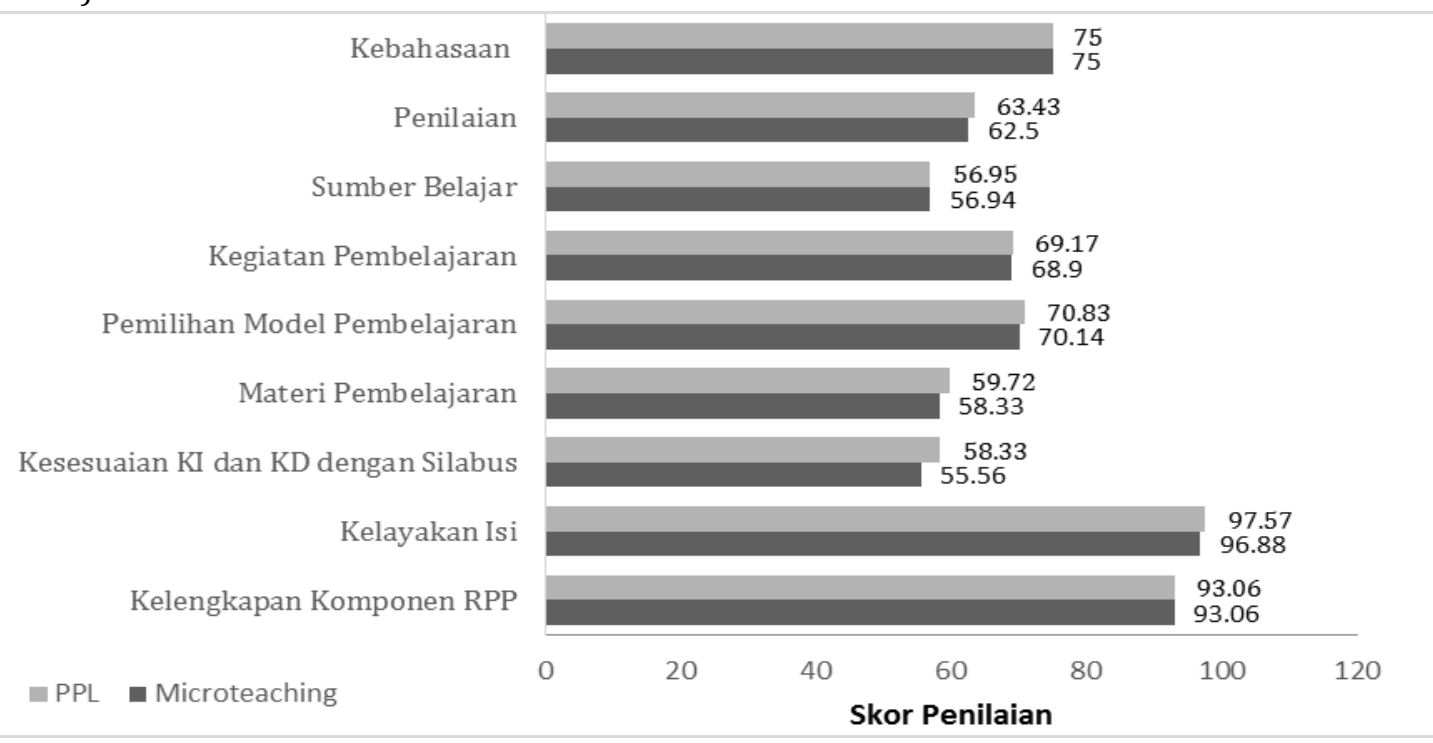

Gambar 1. Hasil Penilaian RPP 
Ummi Nur Afinni Dwi Jayanti, Miza Nina Adlini \& Khairuna, Profil Keterampilan Menyusun Skenario Pembelajaran Mahasiswa Calon Guru Biologi Perguruan Tinggi Keagamaan

JURNAL BIOLOKUS Vol.3 (1)

Komponen RPP terdiri atas: 1) identitas sekolah; 2) identitas mata pelajaran; 3) jenjang kelas dan semester; 4) alokasi waktu; 5) Kompetensi Dasar (KD) dan indikator pencapaian kompetensi; 6) tujuan pembelajaran; 7) materi pembelajaran; 8) metode pembelajaran; 8) media pembelajarn; 9) sumber belajar; 10) tahapan pembelajaran; dan 11) penilaian hasil pembelajaran. Hasil penilaian kelengkapan komponen RPP mahasiswa dapat dilihat pada Gambar 1 diatas.

Hasil pada grafik Gambar 1 menunjukkan bahwa mahasiswa umumnya membuat RPP dengan komponen yang lengkap dengan kelayakan isi yang sangat baik. Selain itu pemilihan model pembelajaran dan bahasa yang digunakan dalam RPP sudah baik. Hasil ini sejalan dengan hasil penelitian Aufa \& Maizeli (2014) yang menunjukkan bahwa kelengkapan RPP yang dibuat oleh guru umumnya sesuai dengan standar yang ditetapkan oleh pemerintah.

Walaupun demikian, terkait kesesuaian KI dan KD dengan silabus, materi pembelajaran, kegiatan pembelajaran, sumber belajar dan penilaian masih dalam kategori kurang baik. Selanjutnya dilakukan analisis lebih dalam terhadap deskriptor dari masing-masing indikator penilaian khususnya pada indikator kelayakan isi, kesesuaian KI dan KD dengan silabus, materi pembelajaran, pemilihan model pembelajaran, kegiatan pembelajaran, sumber belajar dan penilaian.

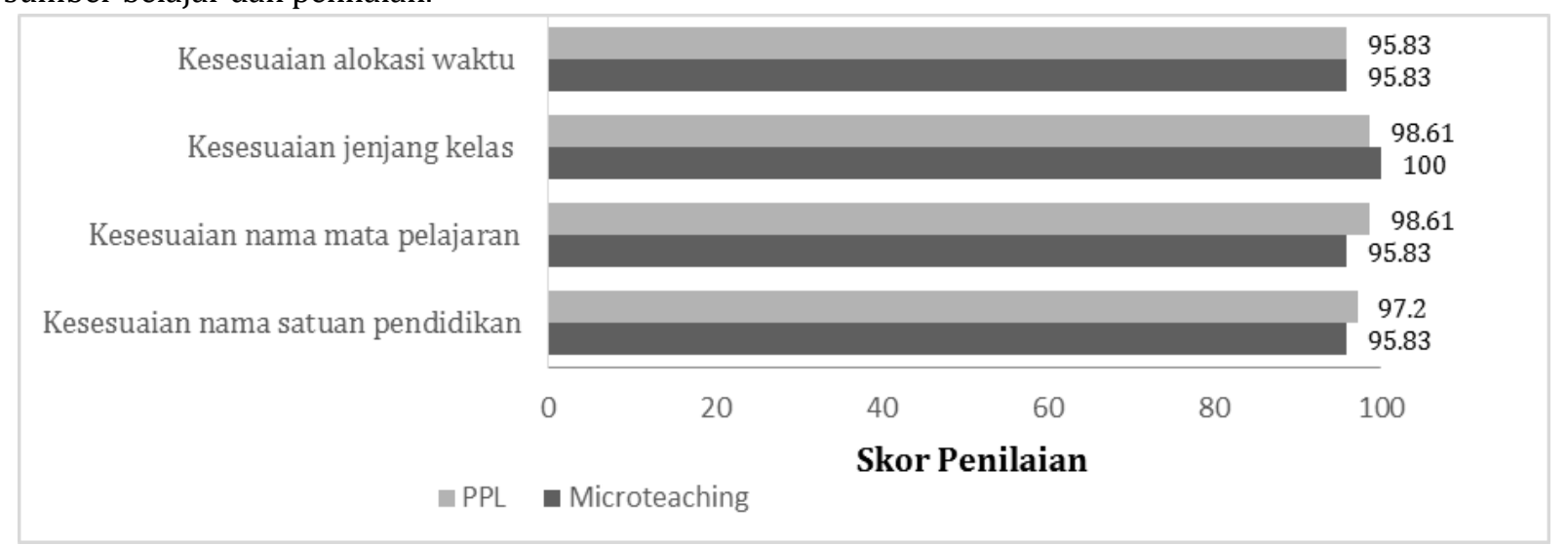

Gambar 2. Perbandingan Deskriptor Indikator Kelayakan Isi RPP Matakuliah Microteaching dan PPL

Selanjutnya, Gambar 3 menunjukkan hasil penilaian terkait indikator kesesuaian KI dan KD dengan silabus. Hasil analisis menunjukkan bahwa kemampuan mahasiswa masih sangat kurang dalam merumuskan indikator dan tujuan pembelajaran. Kemampuan mahasiswa dalam merumuskan indikator mengalami peningkatan sebesar 5,56\% pada RPP yang dibuat dalam mata
Analisis lebih lanjut dilakukan dengan membandingkan komponen RPP yang dibuat mahasiswa pada mata kuliah microteaching dan PPL di sekolah. Indikator kelengkapan komponen RPP dan kebahasaan tidak dipaparkan lebih lanjut karena masing-masing memiliki skor penilaian yang sama pada RPP yang dibuat mahasiswa sebagai hasil perkuliahan microteaching dan PPL di sekolah. Analisis kelayakan isi mencakup kesesuaian nama satuan pendidikan, nama mata pelajaran, jenjang kelas dan alokasi waktu yang dipaparkan dalam identitas RPP. Hasil analisis kelayakan isi RPP mahasiswa dapat dilihat pada Gambar 2 dibawah.

Hasil analisis indikator kelayakan isi RPP menunjukkan mahasiswa sudah sangat baik dalam menuliskan nama satuan pendidikan, mata pelajaran jenjang kelas dan menentukan alokasi waktu. Hasil penilaian RPP yang dibuat sebagai tugas mata kuliah Microteaching dan PPL menunjukkan hasil yang tidak terlalu berbeda. Hasil terkait kesesuaian alokasi waktu pada penelitian ini berbeda dengan hasil penelitian Aufa \& Maizeli (2014) yang menunjukkan bahawa alokasi waktu merupakan satu komponen RPP yang sering tidak dilengkapi oleh guru. Padahal alokasi waktu merupakan hal yang penting untuk penentuan pencapaian kompetensi dasar yang akan dipelajari siswa (Goldsmith, 2009). 
Ummi Nur Afinni Dwi Jayanti, Miza Nina Adlini \& Khairuna, Profil Keterampilan Menyusun Skenario Pembelajaran Mahasiswa Calon Guru Biologi Perguruan Tinggi Keagamaan

JURNAL BIOLOKUS Vol.3 (1)

sistematika penulisan indikator dan komponen dari tujuan pembelajaran. Hasil ini sejalan dengan penelitian (Aufa \& Maizeli, 2014; Ernawati \& Safitri, 2018; Gularso, 2017; Melania, 2014; Nurzain, 2015; Wulandari, 2019) yang melaporkan terkait kesulitan guru dan calon guru dalam merumuskan indikator dan tujuan pembelajaran.
Aspek yang sulit dilakukan guru dalam merumuskan indikator yaitu terkait dengan penentuan Kata Kerja Operasional (KKO) untuk menerjemahkan Kompetensi Dasar serta merumuskan komponen tujuan pembelajaran berupa Audience, Behavior, Condition dan Degree.

Sesuai dengan pendekatan yang disarankuan Kurikulum

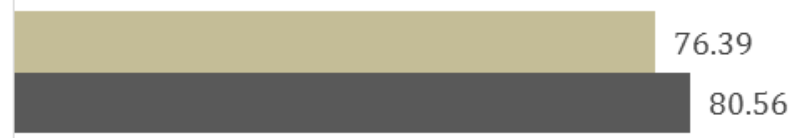

Sesuai dengan tujuan pembelajaran

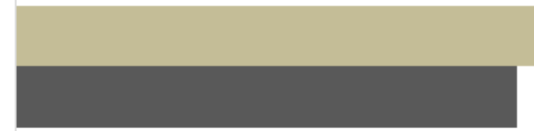

65.28 59.72

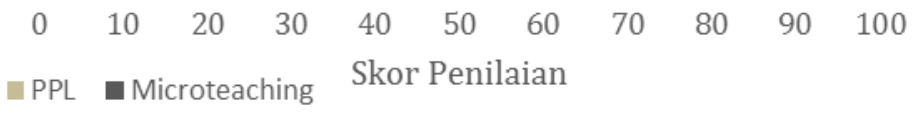

\section{Gambar 3. Penilaian Deskriptor Indikator Kesesuaian KI dan KD dengan Silabus}

Hasil penilaian selanjutnya yaitu terkait perumusan materi pembelajaran dapat dilihat pada Gambar 4. Data pada Gambar 4 menunjukkan bahwa kemampuan mahasiswa masih sangat kurang dalam merumuskan materi kedalam bentuk faktual, konseptual, prosedural atau prinsip dan metakognitif. Hasil ini tidak sesuai dengan ketentuan perumusan materi pembelajaran menurut Permendikbud Nomor 22 tahun 2016
(2016). Kemampuan mahasiswa dalam merumuskan materi pembelajaran yang sesuai dengan karakter juga masih dalam kategori kurang. Hasil penilaian RPP pada mata kuliah microteaching dan pelaksanaan PPL terkait perumusan butir-butir materi pembelajaran serta penyesuaian materi dengan karakter siswa menunjukkan hasil yang sama.

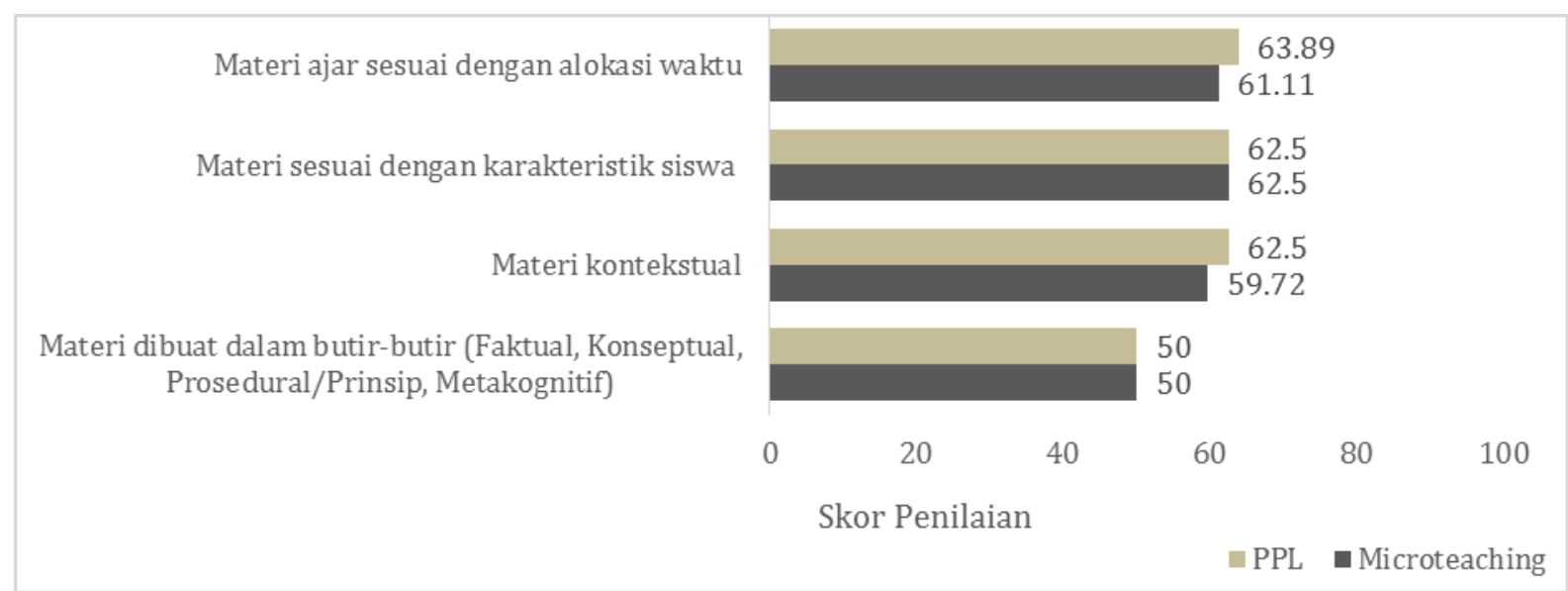

Gambar 4. Perbandingan Penilaian Deskriptor Perumusan Materi Pembelajaran pada RPP Mahasiswa.

Selain itu, kemampuan mahasiswa dalam merumuskan materi pembelajaran yang kontekstual, sesuai dan kesesuaian dengan alokasi waktu masih dalam kategori kurang. Terjadi peningkatan persentase $2,78 \%$ baik pada penilaian RPP dari perkuliahan microteaching dengan RPP kegiatan PPL di sekolah untuk perumusan materi yang kontekstual dan kesesuaian materi ajar dengan alokasi waktu. Hasil ini sejalan dengan penelitian Anggraeni (2009) yang menunjukkan materi yang dirumuskan mahasiswa calon guru masih bersifat teoritis, minim dalam pemilihan materi yang kontekstual dan belum sesuai dengan karakter siswa. 
Ummi Nur Afinni Dwi Jayanti, Miza Nina Adlini \& Khairuna, Profil Keterampilan Menyusun Skenario Pembelajaran Mahasiswa Calon Guru Biologi Perguruan Tinggi Keagamaan

JURNAL BIOLOKUS Vol.3 (1)

Hasil penilaian dekskriptor untuk indikator pemilihan model pembelajaran dalam RPP mahasiswa dapat dilihat pada Gamba 5. Grafik menunjukkan mahasiswa sudah baik dalam memilih model pembelajaran sesuai dengan pendekatan yang disarankan Kurikulum 2013.

Akan tetapi, pemilihan model pembelajaran tersebut masih kurang sesuai dengan tujuan pembelajaran yang dirumuskan. Terjadi kenaikan persentase sebesar 5,56\% dari RPP yang dibuat pada perkuliahan microteaching dengan RPP kegiatan PPL. Sementara itu, terjadi penurunan persentase sebesar 4,17\% untuk kesesuaian model pembelajaran yang dipilih dengan pendekatan yang disarankan Kurikulum.

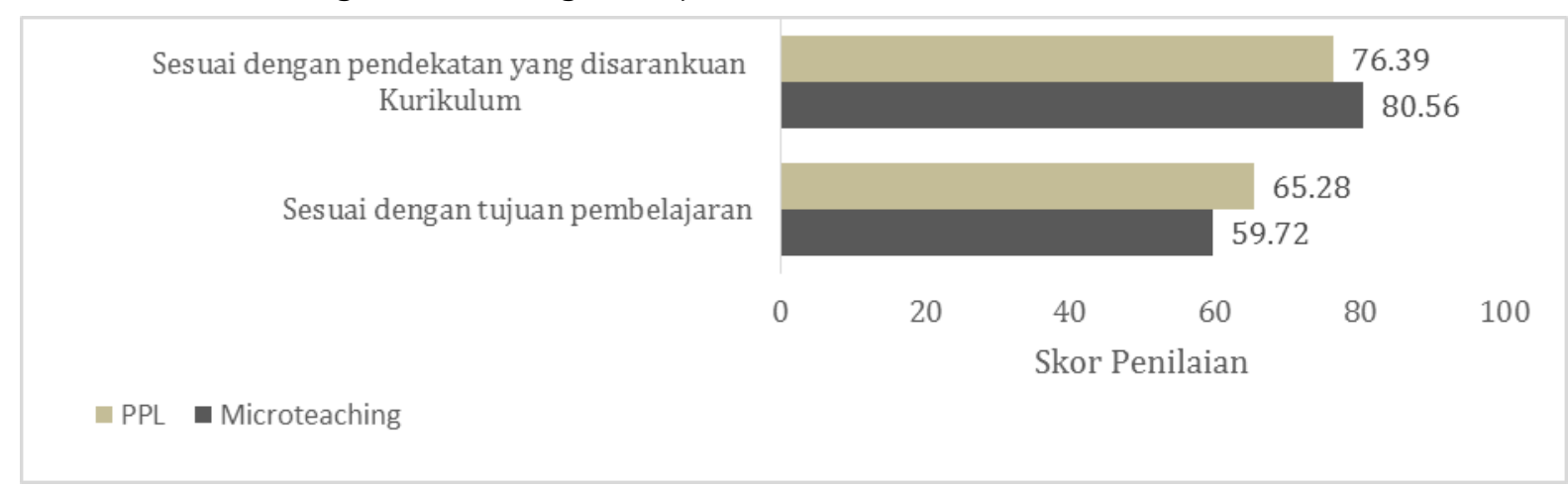

Gambar 5. Perbandingan Penilaian Deskriptor Pemilihan Model Pembelajaran pada RPP Mahasiswa.

Selanjutnya, hasil penilaian deksriptor perumusan kegiatan pembelajaran dapat dilihat pada Gambar 6. Secara umum, kelengkapan komponen kegiatan pembelajaran berupa kegiatan pendahuluan, kegiatan inti dan kegiatan penutup sudah ada pada seluruh RPP yang dibuat oleh mahasiswa. Walaupun demikian, kemampuan mahasiswa dalam merumuskan komponen dari kegiatan pendahuluan, inti dan penutup masih dalam kategori kurang hingga sangat kurang. Persentase paling kecil dengan kategori sangat kurang yaitu terkait kesesuaian kegiatan pembelajaran dengan tujuan pembelajaran yang ingin dicapai pada RPP perkuliahan microteaching dan mengalami peningkatan persentase sebesar $5,56 \%$ pada RPP perkuliahan PPL. Sementara itu, hasil penilaian terkait kesesuaian kegiatan dengan sintaks model pembelajaran presentase berada dalam kategori kurang dengan persentase yang sama baik di RPP yang dibuat dalam perkuliahan microteaching maupun RPP perkuliahan PPL di sekolah.

Sementara itu, hasil penilaian untuk perumusan kegiatan pendahuluan dan kegiatan penutup berada pada kategori cukup. Nilai persentase perumusan kegiatan pendahuluan mengalami peningkatan pada RPP kegiatan PPL daripada pada RPP perkuliahan microteaching. Akan tetapi, nilai persentase perumusan kegiatan penutup mengalami penurunan. Sebesar 5,55\%.

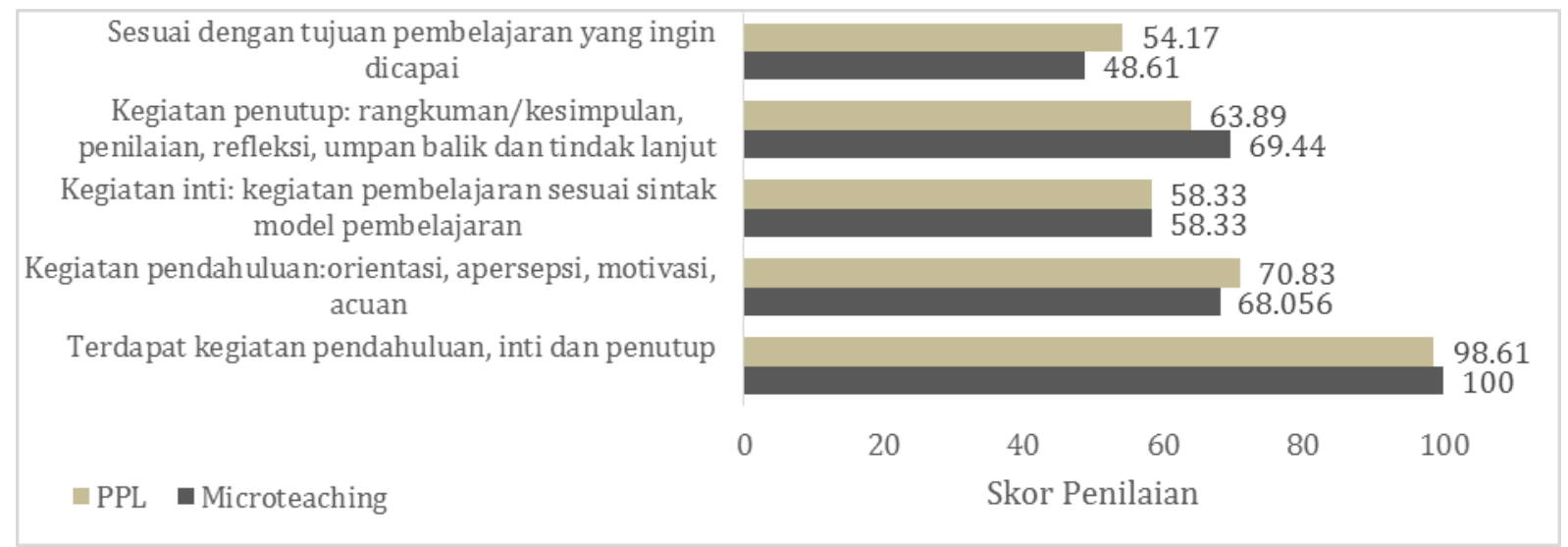

Gambar 6. Perbandingan Penilaian Deskriptor Perumusan Kegiatan Pembelajaran pada RPP Mahasiswa 
Ummi Nur Afinni Dwi Jayanti, Miza Nina Adlini \& Khairuna, Profil Keterampilan Menyusun Skenario Pembelajaran Mahasiswa Calon Guru Biologi Perguruan Tinggi Keagamaan

JURNAL BIOLOKUS Vol.3 (1)

Pada Gambar 7 menunjukkan hasil penilaian berdasarkan indikator penggunaan sumber belajar pada RPP yang dibuat mahasiswa. Berdasarkan Gambar tersebut, kemampuan siswa dalam merumuskan penggunaan sumber belajar masih sangat kurang. Persentase hasil penilaian terhadap variasi sumber belajar yang digunakan pada pelaksanaan microteaching lebih tinggi dari penggunaan sumber belajar pada pelaksanaan PPL. Selain itu, sumber belajar yang digunakan masih belum sesuai dengan rumusan indikator pencapaian kompetensi dan tujuan pembelajaran, dan kegiatan pembelajaran. Nilai persentase kesesuaian sumber belajar dengan KD, materi ajar, kegiatan belajar pada RPP kegiatan PPL lebih tinggi daripada pada RPP matakuliah microteaching. Hasil ini sejalan dengan temuan Anggraeni (2009) bahwa kemampuan mahasiswa calon guru biologi masih kurang dalam memilih sumber belajar yang sesuai dengan karakteristik siswa.

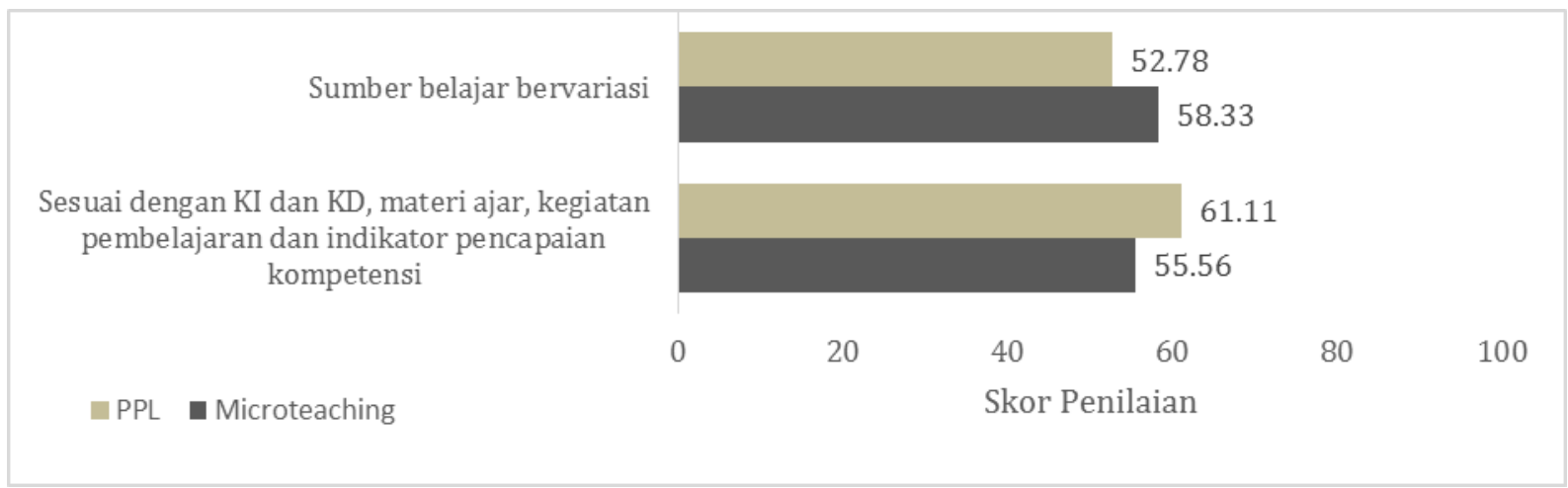

Gambar 7. Perbandingan Penilaian Deskriptor Penggunaan Sumber Pembelajaran pada RPP Mahasiswa

Gambar 8 menunjukkan hasil deskriptor perumusan penilaian pembelajaran. Berdasarkan Gambar 8, kemampuan mahasiswa dalam merumuskan penilaian pembelajaran masih dalam kategori kurang.

Presentasi kemampuan merumuskan penilaian pembelajaran pada RPP di mata kuliah secara umum naik sebesar $2 \%$ untuk indikator kesesuaian prosedur dan instrument dengan indikator pencapaian kompetensi.

Hasil ini sejalan dengan temuan Anggraeni (2009) serta Dewi \& Krismawati (2018) yang menunjukkan bahwa mahasiswa calon guru masih belum terampil dalam merumuskan penilaian pembelajaran pada RPP yang dibuat.
Penilaian dijabarkan atas teknik penilaian, bentuk
instrumen dan instrumen yang digunakan

Prosedur mengacu pada standar penilaian

Prosedur dan instrumen penilaian sesuai dengan indikator pencapaian kompetensi

aPL $\quad$ Microteaching

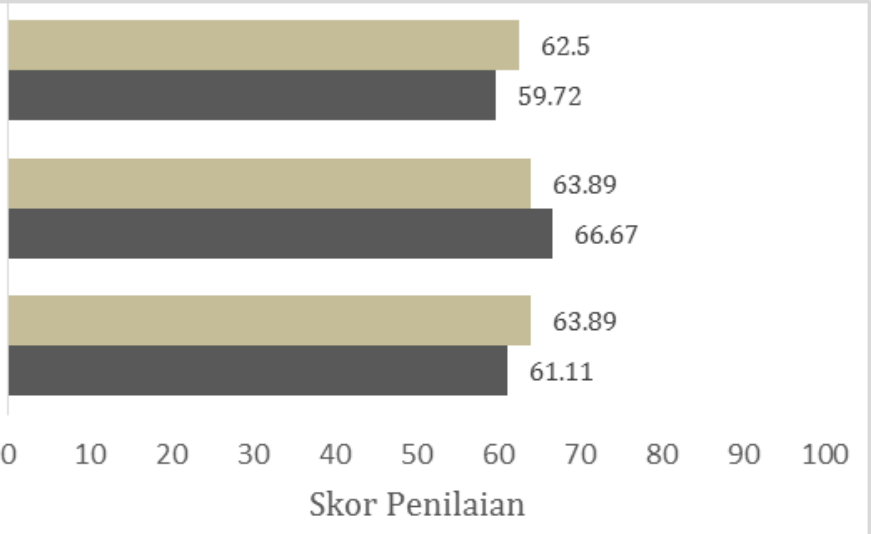

Skor Penilaian

Gambar 8. Perbandingan Penilaian Deskriptor Perumusan Penilaian Pembelajaran

\section{KELEMAHAN RPP MAHASISWA}

Terdapat empat kelemahan yang muncul dari analisis RPP mahasiswa baik pada RPP yang dibuat dalam matakuliah microteaching maupun kegiatan PPL. Empat kelemahan tersebut meliputi penetapan urutan kegiatan pembelajaran, aktivitas guru dan siswa, pemilihan metode dan strategi yang tepat serta kesesuaian kegiatan pembelajaran dengan tujuan pembelajaran. Hasil ini sejalan dengan temuan Dewi \& Krismawati (2018) yang menunjukkan bahwa salah satu faktor kesalahan dalam penyusunan RPP yaitu terkait penyusunan 
Ummi Nur Afinni Dwi Jayanti, Miza Nina Adlini \& Khairuna, Profil Keterampilan Menyusun Skenario Pembelajaran Mahasiswa Calon Guru Biologi Perguruan Tinggi Keagamaan

JURNAL BIOLOKUS Vol.3 (1)

tujuan pembelajaran dan ketidakpahaman dalam menjabarkan rangkaian kegiatan sesuai dengan strategi dan model pembelajaran yang digunakan. Keempat hal tersebut berkaitan dengan kemampuan mahasiswa dalam menyusun skenario pembelajaran.

\section{Menetapkan Urutan Tahapan Kegiatan Pembelajaran}

Berdasarkan hasil analisis RPP mahasiswa baik pada mata kuliah microteaching maupun PPL, mahasiswa secara umum dapat menetapkan tahap kegiatan pembelajaran secara runtut. Urutan tahap kegiatan pembelajaran tersebut yaitu kegiatan pendahuluan, kegiatan inti, dan kegiatan penutup (Permendikbud No 22 Tahun 2016, 2016). Walaupun demikian, terdapat variasi dari urutan komponen dari masing-masing kegiatan pembelajaran tersebut pada RPP mahasiswa.

Komponen dari kegiatan pendahuluan meliputi kegiatan: (1) persiapan psikis dan fisik peserta didik; (2) pemberian motivasi belajar peserta didik terkait penerapan dan manfaat dari materi ajar secara kontekstual; (3) pemberian pertanyaan acuan untuk mengaitkan pengetahuan terdahulu dengan yang akan dipelajari; dan (4) penyampaian kompetensi dasar dan tujuan pembelajaran yang akan dicapai serta cakupan materi yang akan dipelajari (Permendikbud Nomor 22 Tahun 2016, 2016). Hasil analisis menunjukkan bahwa 33,33\% mahasiswa masih belum dapat membedakan apersepsi dan langkah pertama pada kegiatan inti pada RPP kegiatan PPL.

Selanjutnya, analisis dilakukan pada komponen kegiatan inti pada RPP mahasiswa baik pada RPP microteaching maupun RPP PPL. Komponen dari kegiatan inti RPP yaitu kegiatan pembelajaran yang mengacu pada metode, strategi dan model pembelajaran yang digunakan oleh guru serta deskripsi penggunaan media pembelajaran dan sumber belajar yang digunakan (Permendikbud Nomor 22 Tahun 2016, 2016). Kegiatan pembelajaran ini mengacu pada sintaks dari model pembelajaran yang dipilih oleh guru berdasarkan karakteristik siswa dan materi sesuai tuntutan KD.

Walaupun demikian, terdapat empat temuan yang didapatkan dari analisis kegiatan inti RPP mahasiswa, yaitu: (1) 27,78\% mahasiswa tidak mencantumkan sintaks model pembelajaran baik pada RPP microteaching maupun RPP PPL; (2) langkah pembelajaran tidak sesuai dengan sintaks model pembelajaran dengan persentase temuan untuk RPP kegiatan PPL (38,89\%) lebih tinggi dari persentase temuan pada RPP microteaching (16,67\%); (3) mahasiswa belum dapat membedakan sintaks model pembelajaran dengan komponen 5M $(55,56 \%$ untuk RPP microteaching dan 44,44\% untuk RPP PPL); (4) mahasiswa belum mahir memadukan dua model pembelajaran untuk dijadikan acuan kegiatan pembelajaran $(11,11 \%$ pada RPP microteaching dan $16,67 \%$ pada RPP PPL).

Kegiatan pembelajaran selanjutnya yang dianalisis yaitu kegiatan penutup. Komponen dari kegiatan penutup pada RPP mencakup kegiatan menyimpulkan hasil pembelajaran yang telah dilakukan, melakukan refleksi, memberikan tindak lanjut baik berupa tugas individu maupun kelompok serta memberikan informasi terkait rencana kegiatan pembelajaran untuk pertemuan berikutnya (Permendikbud No. 22 tahun 2016, 2016). Hasil analisis RPP menunjukkan bahwa kelemahan yang paling banyak ditemukan pada RPP mahasiswa yaitu terkait dalam perumusan tindak lanjut hasil pembelajaran dan perumusan rencana kegiatan pembelajaran selanjutnya dengan masing-masing persentase temuan sebesar $44,44 \%$ baik pada RPP microteaching dan RPP PPL.

\section{Menetapkan Aktivitas Guru dan Siswa}

Hasil analisis menunjukkan bahwa aktivitas guru dan siswa pada RPP mahasiswa masih belum dideskripsikan secara jelas (100\% pada RPP PPL dan $72,22 \%$ pada RPP microteaching). Mahasiswa cenderung menyusun langkah pembelajaran hanya mencantumkan kegiatan dan alokasi saja tanpa membagi penjelasan kegiatan pembelajaran dengan deskripsi kegiatan yang dilakukan guru dan kegiatan yang dilakukan oleh siswa. Bahkan terdapat RPP yang tidak mencantumkan sintaks model pembelajaran. Hal ini menyebabkan orang lain yang membaca RPP tersebut tidak dapat memahami apa maksud dari kegiatan pembelajaran yang dilakukan dan bagaimana suatu materi dibelajarkan dengan suatu model pembelajaran tertentu. Perencanaan aktivitas pembelajaran secara detail merupakan hal yang paling penting untuk meningkatkan keefektifan pengajaran yang dilakukan oleh guru (Dunn \& Shriner, 1999). Selain itu, perencanaan yang detail menyediakan waktu pembelajaran yang lebih untuk siswa melaksanakan 
Ummi Nur Afinni Dwi Jayanti, Miza Nina Adlini \& Khairuna, Profil Keterampilan Menyusun Skenario Pembelajaran Mahasiswa Calon Guru Biologi Perguruan Tinggi Keagamaan

JURNAL BIOLOKUS Vol.3 (1)

tugas dan berdampak pada kesempatan belajar yang lebih banyak (Naafs et al., 2002).

\section{Memilih Metode dan Strategi Yang Tepat Sesuai Karakteristik Materi}

Salah satu komponen RPP yang sangat krusial yaitu langkah pembelajaran yang didalamnya mencakup kegiatan pembelajaran yang akan dilakukan pada pertemuan tertentu dan materi tertentu. Pengetahuan guru tentang berbagai pendekatan, metode, strategi dan model pembelajaran merupakan hal yang penting sebagai dasar menentukan langkah pembelajaran (Wegner, Minnaert, \& Strehlke, 2013). Pemilihan pendekatan, metode, strategi dan model pembelajaran harus memperhatikan karakteristik peserta didik dan materi mata pelajaran serta memfasilitasi pengembangan sikap, pengetahuan dan keterampilan siswa (Permendikbud No. 22 Tahun 2016, 2016). Terdapat dua kekurangan mahasiswa terkait pemilihan pendekatan, metode, strategi dan model pembelajaran yang tepat baik pada RPP microteaching maupun RPP PPL.

Pertama, pendekatan yang dipilih oleh mahasiswa tidak sesuai dengan metode, model dan deskripsi kegiatan yang dilakukan dengan persentase $16,67 \%$ pada RPP PPL dan $11,11 \%$ pada RPP Microteaching. Contoh temuannya yaitu pada salah satu RPP Microteaching dan RPP PPL mencantumkan pendekatan saintifik namun strategi, model dan kegiatan pembelajarannya menggambarkan langkah pembelajaran kooperatif. Pembelajaran kooperatif merupakan model pembelajaran yang menggunakan pendekatan berpusat pada siswa (student-centered approach) (Arends, 2012) dan bukan pendekatan saintifik. Selain itu, model pembelajaran kooperatif mempunyai banyak tipe, sehingga hendaknya mahasiswa memilih sintaks salah satu tipe pembelajaran kooperatif tersebut untuk dijadikan sebagai acuan perumusan kegiatan pembelajaran.

Kedua, terdapat ketidaksesuaian model pembelajaran dengan karakteristik materi. Walaupun frekuensi temuan kesalahan ini hanya 5,56\% baik pada RPP microteaching dan RPP PPL, hal ini perlu mendapatkan perhatian karena kesesuaian model pembelajaran dengan karakteristik materi akan menentukan ketercapaian dari KD dan tujuan pembelajaran yang telah dirumuskan. Contoh temuan terkait hal ini yaitu pemilihan model pembelajaran kooperatif untuk membelajarkan materi struktur jaringan tumbuhan dan pemilihan model Direct Instruction dan pembelajaran kooperatif untuk membelajarkan materi klasifikasi tumbuhan lumut. Analisis lebih dalam terkait temuan tersebut dilakukan dengan memperhatikan karakteristik biologi sebagai produk, proses dan nilai dengan karakteristik dari model pembelajaran kooperatif dan Direct Instruction serta tuntutan penguasaan Kompetensi Dasar pada Kurikulum.

Biologi, sebagai bagian dari Ilmu Pengetahuan Alam, memiliki karakteristik yang berbeda dengan rumpun Ilmu Alam lainnya. Biologi memiliki karakteristik sebagai produk, proses dan nilai. Konsep Biologi yang dipelajari di sekolah merupakan produk yang dihasilkan dari kegiatan empiris dan analisis yang dilakukan oleh ilmuwan terdahulu melalui metode ilmiah. Selain itu, Biologi mengandung nilai-nilai yaitu mengandung muatan keimanan dan penghayatan ajaran agama dan memuat nilai-nilai karakter mulia yang merupakan hasil proses pembelajaran saintifik (S. K. Dewi, Kristiani, \& Mulyana, 2016). Berdasarkan karakteristik Biologi tersebut, maka dalam mengajarkan Biologi, guru disarankan untuk memilih pendekatan, metode, strategi dan model pembelajaran yang didalamnya memuat metode ilmiah, yaitu pendekatan saintifik. Model pembelajaran dengan pendekatan saintifik yang disarankan oleh Kurikulum 2013 antara lain discovery learning, inquiry learning, problem based learning dan project based learning (Permendikbud Nomor 22 Tahun 2016, 2016).

Model pembelajaran kooperatif, walaupun merupakan salah satu model pembelajaran konstruktivis berpusat pada siswa, namun langkah kegiatan pembelajarannya tidak memuat metode ilmiah. Keluaran yang diharapkan dari model pembelajaran kooperatif mencakup hasil belajar, toleransi akan keberagaman kelas serta skill siswa dalam bersosialisasi dengan teman sekelas. Sementara itu, model pembelajaran direct instruction merupakan model pembelajaran berpusat pada guru untuk membantu siswa mempelajari skill penting dalam mempelajari suatu materi (Arends, 2012). Model pembelajaran ini dalam pembelajaran Biologi cocok diterapkan jika guru ingin memberikan materi terkait penggunaan alat laboratorium seperti penggunaan mikroskop.

Pemahaman terkait karakteristik Biologi dan karakteristik model pembelajaran kooperatif 
Ummi Nur Afinni Dwi Jayanti, Miza Nina Adlini \& Khairuna, Profil Keterampilan Menyusun Skenario Pembelajaran Mahasiswa Calon Guru Biologi Perguruan Tinggi Keagamaan

JURNAL BIOLOKUS Vol.3 (1)

dan direct instruction tersebut kemudian diintegrasikan dengan memperhatikan tuntutan Kompetensi Dasar Kurikulum. Tuntutan KD pada dokumen Kurikulum 2013 untuk materi struktur dan fungsi jaringan tumbuhan yaitu menganalisis keterkaitan antara struktur jaringan dan fungsi organ tumbuhan dan menyajikan data hasil pengamatan struktur anatomi jaringan tumbuhan. Sementara itu, tuntutan KD untuk materi klasifikasi tumbuhan yaitu menerapkan prinsip klasifikasi untuk menggolongkan tumbuhan ke dalam divisi berdasarkan pengamatan dan metagenesis tumbuhan (Permendikbud Nomor 37 Tahun 2018, 2018).

Penguasaan kompetensi dari kedua materi tersebut menuntut adanya suatu proses pengamatan dalam kegiatan pembelajaran sehingga model pembelajaran yang cocok untuk membelajarkan materi tersebut adalah model pembelajaran dengan pendekatan saintifik. Model pembelajaran kooperatif tidak cocok digunakan karena di dalam kegiatannya tidak memberikan pengalaman belajar melalui kegiatan pengamatan tumbuhan dan serangkaian metode ilmiah lainnya untuk menerapkan prinsip klasifikasi tumbuhan serta pengamatan struktur anatomi jaringan tumbuhan untuk mengetahui keterkaitan struktur tumbuhan dengan fungsinya.

\section{Menetapkan Estimasi Waktu Untuk Setiap Kegiatan Pembelajaran}

Hasil analisis RPP mahasiswa menunjukkan 27,80\% (pada RPP PPL) mahasiswa masih belum memahami terkait alokasi jam pelajaran (JP) untuk satu kali pertemuan dan $11,11 \%$ (pada RPP microteaching) pembagian alokasi waktu tidak tepat. Alokasi waktu pada RPP mahasiswa masih ada yang menuliskan "1kali pertemuan"; "2 kali pertemuan"; "2" dan "1x105 menit". Hal ini tidak sesuai dengan aturan alokasi waktu pembelajaran yang telah ditetapkan pemerintah. Alokasi waktu jam tatap muka untuk satu jam pelajaran (JP) di jenjang SMP dan SMA/MA yaitu selama 40 menit dan 45 menit (Permendikbud No. 22 tahun 2016, 2016). Sementara itu, untuk satu kali pertemuan alokasi waktu yang ditetapkan yaitu 2 x 40 menit untuk jenjang SMP dan $2 \times 45$ menit untuk jenjang SMA. Alokasi JP/minggu untuk mata pelajaran biologi SMA kelas $\mathrm{X}$ yaitu 3JP/minggu sedangkan untuk kelas XI dan XII 4JP/minggu. Sementara itu alokasi waktu mata pelajaran IPA SMP untuk setiap jenjang kelas yaitu 5 JP/Minggu (Permendikbud Nomor 68 Tahun 2013, 2013).

Pembagian JP tersebut menuntut guru untuk dapat merencanakan alokasi waktunya sebaik dan seefisien mungkin agar kompetensi dasar dan tujuan pembelajaran yang ditetapkan dapat tercapai (Goldsmith, 2009). Guru harus menetapkan estimasi waktu di setiap kegiatan pembelajaran mulai dari kegiatan pendahuluan hingga penutup. Penetapan alokasi waktu pada kegiatan pembelajaran hendaknya dibuat secara detail dan rasional dengan memperhatikan tingkat kekompleksan kegiatan pembelajaran. Walaupun demikian, pembagian alokasi waktu pada RPP mahasiswa masih tidak detail dengan persentase temuan kesalahan lebih tinggi pada RPP PPL $(77,78 \%)$ daripada RPP microteaching $(44,44 \%)$. Sementara itu, $16,67 \%$ dari RPP PPL tidak mencantumkan alokasi waktu pada setiap kegiatan pembelajarannya. Hasil ini sejalan dengan penelitian (Aufa \& Maizeli, 2014) terkait kecenderungan guru untuk tidak mencantumkan alokasi waktu pada RPP yang dibuat.

\section{Penyusunan Kegiatan Pembelajaran Sesuai Dengan Tujuan Pembelajaran}

Hasil analisis menunjukkan 94,44\% mahasiswa menyusun kegiatan pembelajaran yang tidak sesuai dengan tujuan pembelajaran pada RPP microteaching. dan $83,33 \%$ pada RPP PPL. kegiatan pada kegiatan inti RPP. Contoh temuan pada RPP mahasiswa dapat dilihat pada Tabel 3. Berdasarkan Tabel 3, diketahui bahwa perumusan tujuan pembelajaran tidak mengikuti kaidah penulisan tujuan pembelajaran sehingga gambaran mengenai proses dan perilaku hasil belajar pada tujuan yang dirumuskan tidak sinkron dengan rumusan kegiatan pembelajaran. Perumusan tujuan pembelajaran perlu memperhatikan salah satu kaidah behaviorism maupun non-behaviorism (Kementerian Pendidikan dan Kebudayaan, 2020). Kompenen dari kaidah behaviorism mencakup kepada siapa tujuan pembelajaran ditujukan (Audience), hasil belajar atau perilaku yang ingin ditunjukkan oleh peserta didik (Behavior), keadaan bagaimana siswa diharapkan menunjukkan hasil belajar (Condition), dan tingkat keberhasilan yang ditargetkan (Degree).

Sementara itu, komponen dari kaidah nonbehaviorisme mencakup siapa yang mengikuti proses pembelajaran (Audience), perilaku siswa 
Ummi Nur Afinni Dwi Jayanti, Miza Nina Adlini \& Khairuna, Profil Keterampilan Menyusun Skenario Pembelajaran Mahasiswa Calon Guru Biologi Perguruan Tinggi Keagamaan

JURNAL BIOLOKUS Vol.3 (1)

selama mengikuti proses pembelajaran (Behavior) dan cakupan materi yang terdiri atas pengetahuan, sikap dan keterampilan abstrak yang dingin dicapai (Content). Tujuan pembelajaran pada nomor 1 hanya memuat komponen Audience (siswa) dan Behavior (menjelaskan komponen penyusun ekosistem) tanpa ada keterangan condition dan degree (kaidah behaviorism) maupun
Content (kaidah non-behaviorism). Sementara itu, pada tujuan pembelajaran nomor 2 tidak mencantumkan siswa sebagai komponen Audience maupun komponen Degree (untuk kaidah ABCD). Selain itu untuk komponen Condition masih kurang dijelaskan terkait "melalui percobaan" apa yang dilakukan untuk mencapai Behavior yang diharapkan.

Tabel 3. Tujuan Pembelajaran dan Kegiatan pada RPP Mahasiswa.

\begin{tabular}{|c|c|c|c|}
\hline No & TP & MP & KP \\
\hline 1 & $\begin{array}{l}\text { Siswa mampu } \\
\text { menjelas-kan kom- } \\
\text { ponen penyusun } \\
\text { ekosistem }\end{array}$ & $\begin{array}{l}\text { Problem } \\
\text { Based } \\
\text { Learning }\end{array}$ & $\begin{array}{l}\text { - Memberi-kan fotocopy materi } \\
\text { - Siswa menggaris bawahi kata-kata penting } \\
\text { - Berdiskusi kelompok menjawab pertanyaan } \\
\text { - Presentasi }\end{array}$ \\
\hline 2. & $\begin{array}{l}\text { Untuk dapat mem- } \\
\text { bedakan mekanis-me } \\
\text { per-napasan dada dan } \\
\text { perut melalui } \\
\text { percobaan }\end{array}$ & $\begin{array}{l}\text { Think } \\
\text { Pair Share }\end{array}$ & $\begin{array}{l}\text { - Penjelasan materi oleh guru } \\
\text { - Membagi siswa dalam kelompok ( } 2 \text { orang/ kelompok) } \\
\text { - Setiap individu berpikir terkait per-masalahan pada } \\
\text { LKS } \\
\text { - Diskusi kelompok } \\
\text { - presentasi }\end{array}$ \\
\hline
\end{tabular}

Ket.

TP: Tujuan Pembelajaran

MP: Model Pembelajaran

KP: Kegiatan Pembelajaran

Selanjutnya, ketidaksesuaian karakteristik model pembelajaran dengan karakteristik materi juga mengakibatkan ketidaksesuaian tujuan pembelajaran dengan langkah pembelajaran. Hal ini tidak sesuai dengan maksud dari penyusunan tujuan pembelajaran yaitu untuk memudahkan guru dalam memilih strategi, teknologi, media serta metode dan instrumen penilaian (Edinyang, 2016; Yousefkhani, 2008). Ketidaksesuaian tujuan pembelajaran 1 pada Tabel 3 dengan langkah pembelajaran dapat dilihat dari kegiatan pembelajaran yang tidak sesuai dengan karakteristik model pembelajaran walaupun dari segi keterkaitan model pembelajaran dengan tuntutan materi pada KD sudah sesuai.

Penggunaan model Problem Based Learning pada pembelajaran sains didasarkan pada pemberian masalah yang ill-structured (Chin \& Chia, 2006; Folmer, Barbosa, \& Soares, 2009; Ge, Law, \& Huang, 2016; Marra, Jonassen, Palmer, \& Luft, 2014) untuk kemudian dipecahkan solusinya melalui serangkaian kegiatan eksplorasi konsep pada suatu bahasan materi (Dogru, 2008). Akan tetapi pada Tabel 3 dapat dilihat bahwa kegiatan pembelajaran untuk tujuan pembelajaran 1 tidak sesuai dengan karakteristik dari model pembelajaran Problem Based Learning. Kegiatan pembelajaran yang dilakukan siswa hanya membaca materi, lalu menggaris bawahi dan mendiskusikan hal yang penting dari materi yang diberikan lalu mempresentasikan.

Selanjutnya, untuk tujuan pembelajaran 2 disebutkan condition yaitu melalui kegiatan percobaan. Hal ini mengindikasikan metode ilmiah yang akan digunakan. Akan tetapi, pada model pembelajaran yang digunakan yaitu model pembelajaran kooperatif Think Pair Share yang didalam sintaksnya tidak memuat komponen metode ilmiah karena tujuan dari penggunaan model ini untuk memberikan waktu bagi siswa berpikir terkait permasalahan yang diberikan guru untuk kemudian didiskusikan dengan diskusi kelompok kecil berjumlah dua orang (Arends, 2012). Dengan demikian, kegiatan pembelajaran yang dirumuskan tidak sesuai dengan tujuan yang diharapkan.

Hasil pemaparan sebelumnya menunjukkan bahwa perumusan tujuan pembelajaran sesuai kaidah, pemahaman tentang karakteristik model pembelajaran dan karakteristik materi pada KD sangat berkaitan dengan kesesuaian tujuan 
Ummi Nur Afinni Dwi Jayanti, Miza Nina Adlini \& Khairuna, Profil Keterampilan Menyusun Skenario Pembelajaran Mahasiswa Calon Guru Biologi Perguruan Tinggi Keagamaan

JURNAL BIOLOKUS Vol.3 (1)

pembelajaran dengan kegiatan pembelajaran. Mahasiswa perlu dibekali pemahaman yang komprehensif terkait hal tersebut agar dapat merumuskan kegiatan pembelajaran yang lebih baik. Harapannya, kemampuan mahasiswa dalam menyusun skenario pembelajaran akan semakin baik sehingga tuntutan Kompetensi Dasar dapat tercapai (Ruys et al., 2012). Perencanaan pembelajaran secara rinci mempunyai hubungan positif dengan hasil belajar siswa (Frudden, 2001; Naafs et al., 2002) serta meningkatkan kualitas dari perilaku instruksional guru dalam mengajar (Meyen \& Greer, 2009).

\section{PENUTUP}

Penelitian ini bertujuan untuk mengetahui gambaran keterampilan mahasiswa dalam menyusun skenario pembelajaran melalui analisis komponen RPP mahasiswa. Hasil penelitian menunjukkan bahwa keterampilan mahasiswa dalam menyusun skenario pembelajaran masih dalam kategori kurang terampil. Hal ini didukung oleh hasil temuan kelemahan RPP mahasiswa pada aspek perumusan skenario pembelajaran mencakup penentuan urutan kegiatan pembelajaran, penetapan aktivitas guru dan siswa, kesesuaian metode, strategi, dan model pembelajaran yang digunakan dengan karakteristik materi dan tuntutan KD, serta kesesuaian kegiatan pembelajaran dengan tujuan pembelajaran.

Implikasi dari penelitian ini yaitu perlunya reformasi dalam penyampaian materi perkuliahan strategi pembelajaran dan perencanaan pembelajaran yang berfokus pada pemahaman secara komprehensif terkait keterkaitan tuntutan KD dan karakteristik materi terhadap penentuan model pembelajaran; pemahaman terkait sintaks model pembelajaran dan perumusannya dalam mata pelajaran biologi; serta pemahaman mendalam terkait perbedaan 5M dengan sintaks model pembelajaran. Selain itu, mengingat bias sains dari sampel, penelitian dapat dilanjutkan dengan penggunaan sampel yang lebih banyak dan dengan menggunakan metode sampling yang hasilnya dapat digeneralisasikan untuk profil keterampilan menyusun skenario pembelajaran mahasiswa calon guru di Indonesia.

\section{REFERENSI}

Agustina, P. \& Saputra, A. (2017). Profil Keterampilan Dasar Mengajar Mahasiswa Calon Guru Biologi pada Matakuliah Microteaching. BIOEDUKATIKA, 5(1), 18-28.

Anggraeni, S. (2009). Sudahkan Calon Guru Biologi Merencanakan Pembelajaran Biologi yang Sesuai dengan Hakikat Sains? Prosiding Seminar Nasional Penelitian, Pendidikan Dan Penerapan MIPA. Fakultas MIPA, Universitas Negeri Yogyakarta.

Arends, R. (2012). Learning to Teach 9th Edition. New York: McGraw-Hill.

Aufa, A. L., \& Maizeli, A. (2014). Analisis Rencana Pelaksanaan Pembelajaran (RPP) Biologi Siswa Kelas VIII Semester I Di SMP Negeri 1 Lembah Melintang Kabupaten Pasaman Barat. Jurnal Wisuda Ke-19 Mahasiswa Prodi Biologi STKIP PGRI Sumbar, 4(2).

Chin, C., \& Chia, L. G. (2006). Problem-based learning: Using ill-structured problems in biology project work. Science Education, 90(1), 44-67. https://doi.org/10.1002/sce.20097

Departemen Pendidikan Nasional. (2005). UndangUndang Nomor 14 Tahun 2005 tentang Guru dan Dosen.

Dewi, R. P., \& Krismawati, S. (2018). Kemampuan menyusun perangkat rencana pelaksanaan pembelajaran mahasiswa program studi pendidikan bahasa dan sastra indonesia angkatan 2014 tahun akademik 2016/2017. Pertemuan Ilmiah Bahasa Dan Sastra Indonesia (PIBSI), XL, 633-648.

Dewi, S. K., Kristiani, N., \& Mulyana, B. (2016). Modul Pelatihan Implementasi Kurikulum 2013 Ilmu Pengetahuan ALam (IPA). Jakarta: Direktorat Pembinaan Sekolah Menengah Atas Direktorat Jenderal Pendidikan Dasar dan Menengah Kementerian Pendidikan dan Kebudayaan.

Dogru, M. (2008). The Application of Problem Solving Method on Science Teacher Trainees on the Solution of the Environmental Problems. Journal of Environmental \& Science Education, 3(1), 9-18.

Dunn, F.G.; Shriner, C. (1999). Deliberate practice in teaching: what teachers do for self improvement? Teaching and Teacher Education, 15, 731-651.

Edinyang, S. (2016). The Necessity Of Instructional 
Ummi Nur Afinni Dwi Jayanti, Miza Nina Adlini \& Khairuna, Profil Keterampilan Menyusun Skenario Pembelajaran Mahasiswa Calon Guru Biologi Perguruan Tinggi Keagamaan

JURNAL BIOLOKUS Vol.3 (1)

Objectives In The Teaching And Learning Of Social Studies Education. Education for Today. Education For Today, 12(2), 46-52.

Ernawati, E., \& Safitri, R. (2018). Analisis Kesulitan Guru Dalam Merancang Rencana Pelaksanaan Pembelajaran Mata Pelajaran Fisika Berdasarkan Kurikulum 2013 Di Kota Banda Aceh. Jurnal Pendidikan Sains Indonesia, 5(2), 49-56.

https://doi.org/10.24815/jpsi.v5i2.9817

Folmer, V., Barbosa, N. B. D. V., \& Soares, F. a. (2009). Experimental activities based on illstructured problems improve Brazilian school students ' understanding of the nature of scientific knowledge. Revista Electrónica de Enseñanza de Las Ciencias, 8, 232-254.

Frudden, S. J. (2001). Lesson plan can make a difference in evaluation teachers. Education, 104(4), 351-353.

Gay, L.R.; Geoffrey, E. Mills; Peter, W. A. (2012). Educational Research Competencies for Analysis and Applications 10th Edition. In 經濟研究. United States: Pearson Education, Inc.

Ge, X., Law, V., \& Huang, K. (2016). Detangling the interrelationships between self-regulation and ill-structured problem solving in problembased learning. Interdisciplinary Journal of Problem-Based Learning, 10(2). https://doi.org/10.7771/1541-5015.1622

Geijsel, F.P.; Sleegers P.J.; Stoel, R.D.; Kruger, M. L. (2009). The Effect of Teacher Psychological and School Organizational and Leadership Factors on Teachers' Professional Learning in Dutch Schools. The Elementary School Journal, 109(4), 406-427.

Goldsmith, J. (2009). Pacing and time allocation at the micro-and meso-level within the class hour: Why pacing is important, how to study it, and what it implies for individual lesson planning. Bellaterra: Journal of Teaching \& Learning Language \& Literature, 1(1), 30-48.

Gularso, D. (2017). Analisis Kesulitan Dalam Perencanaan Pembelajaran Tematik Di Sekolah Dasar. JURNAL JPSD (Jurnal Pendidikan Sekolah Dasar), 3(2), 62-74. https://doi.org/10.26555/jpsd.v3i2.a8171

Halpern, D. (2002). Thought and Knowledge 4th Edition (N. Mahwah, Ed.). Lawrence Erlbaum.
Hanifa, H. (2017). Meningkatkan Kemampuan Guru dalam Menyusun Perencanaan Pembelajaran Melalui Pembinaan Kolaboratif Bagi Guru Kelas V di Dabin II Unit Pendidikan Kecamatan Gedangan. PEDAGOGIA: Jurnal Pendidikan, 6(2), 194-211. https://doi.org/10.21070/pedagogia.v6i2.939

Jayanti, U. N. A. D. (2018). Pengembangan Modul Biologi Berbasis Guided Inquiry Terintegrasi dengan Potensi dan Kearifan Lokal Taman Hutan Raya Wan Abdul Rahman serta Pengaruhnya terhadap Keterampilan Berpikir Kritis, Metakognisi dan Keterampilan Proses Sains Siswa Kelas X SMA di Lam. Universitas Negeri Malang.

Jemmi, A. (2013). Peningkatan Kompetensi Guru Bidang Pendidikan di Kabupaten Tana Tidung. E-Journal Pemerintahan Integratif, 1, 38-50.

Kementerian Pendidikan dan Kebudayaan (2020). Tanya Jawab Rencana Pelaksanaan Pembelajaran (RPP). Jakarta: Kementerian Pendidikan dan Kebudayaan Direktorat Jenderal Pendidikan Anak Usia Dini, Pendidikan Dasar, dan Pendidikan Menengah.

Peraturan Menteri Pendidikan dan Kebudayaan Nomor 68 tahun 2013. (2013). Lampiran Peraturan Menteri Pendidikan an Kebudayaan Nomor 68 Tahun 2013 tentang Kerangka Dasar dan Struktur Kurikulum Sekolah Menengah Pertama/Madrasah Tsanawiyah.

Peraturan Menteri Pendidikan dan Kebudayaan Nomor 22 tahun 2016. (2016). Lampiran Peraturan Menteri Pendidikan dan Kebudayaan Nomor 22 tahun 2016.

Peraturan Menteri Pendidikan dan Kebudayaan Nomor 37 tahun 2018. (2018). Perubahan Atas Peraturan Menteri Pendidikan dan Kebudayaan Nomor 24 Tahun 2016 tentang Kompetensi Inti dan Kompetensi Dasar Pelajaran pada Kurikulum 2013 pada Pendidikan Dasar dan Pendidikan Menengah.

Koehler, A. A. (2015). Developing Preservice Teachers Instructional Design Skills Through Case-Based Instruction: Examining the Impact of Discussion Format and Use Web 2.0 Tools. Retrieved from http://www.buffalo.edu/library.buffalo.edu/

Lestari, K. B. (2018). Keterampilan Dasar Mengajar Mahasiswa Pendidikan Biologi Fkip Ums Pada Mata Kuliah Micro Teaching Tahun Akademik $2017 / 2018$. 
Ummi Nur Afinni Dwi Jayanti, Miza Nina Adlini \& Khairuna, Profil Keterampilan Menyusun Skenario Pembelajaran Mahasiswa Calon Guru Biologi Perguruan Tinggi Keagamaan

JURNAL BIOLOKUS Vol.3 (1)

Luzyawati, L. (2015). Profil Tingkat Penguasaan Keterampilan Dasar Mengajar Mahasiswa Calon Guru Biologi. Jurnal Pengajaran Matematika Dan Ilmu Pengetahuan Alam, 20(1), 88-93. https://doi.org/10.18269/jpmipa.v20i1.568

Marra, R., Jonassen, D., Palmer, B., \& Luft, S. (2014). Why Problem-Based Learning Works: Theoretical Foundations. Journal on Excellence in College Teaching, 25, 221-238.

Melania, L. (2014). Analisis Kesulitan Guru Sekolah Dasar Dalam Implementasi Pendekatan Saintifik Pada Pembelajaran Tema Indahnya Persahabatan Di Kelas 3 Sd Gugus 3 Lowokwaru Kota Malang. Prosiding SEMNAS KSDP: Konstelasi Pendidikan Dan Kebudayaan Indonesia Di Era Globalisasi, 239-246.

Meyen, E. \& Greer, D. (2009). The role of instructional planning in math instruction for students with learning disabilities. Focus on Exceptional Children, 41(5), 1-12.

Naafs, F.; Van de Oord, I., Kenter, B., \& Wilthink, H. (2002). Effectieve instructie: leren lesgeven met het activerende directe instructie model (Effectiv instruction: learning to teaching with the activating direct instruction model. Amersfoort: CPS.

Nurzain, L. (2015). Analisis Rencana Pelaksanaan Pembelajaran (Rpp) Matematika Kurikulum 2013 Kelas X Semester 1 Tahun Ajaran 2014/2015 Di Man Babakan Tegal. Universitas Islam Negeri Walisongo.

Omoteso, B. \& Samudara, A. (2011). The Relationship between Teachers' Effectiveness and Management of Classroom Misbehaviors in Secondary Schools. Psychology, 2, 902-908.

Pinksky, L.E., Monson, D. \& Irby, D. M. (1998). How Excellent Teachers are Made: Reflection on Success to Improve Teaching Advances in Health Science Education. Advances in Healt Science Education, 3, 207-215.

Pinksy, L.E \& Irby, D. M. (1997). "If at First You Don't Succeed": Using Failure to Improve Teaching. Academic Medicine, 72(11), 973976.

Rockoff, J. E. (2004). The Impact of Individual Teachers on Student Achievement: Evidence from Panel Data. American Economic Review, 94(2), 247-252.
Rohayati, E.; Diana, S.W., \& Priyandoko, D. (2018). Lesson Plan Profile of Senior High School Biology Teachers in Subang. Journal of Physics: Conference Series, 1013012003.

Ruys, I., van Keer, H., \& Aelterman, A. (2012). Examining pre-service teacher competence in lesson planning pertaining to collaborative learning. Journal of Curriculum Studies, 44(3), 349-379.

https://doi.org/10.1080/00220272.2012.675 355

Safardi. (2009). Perencanaan Pembelajaran. Jakarta: PT. Bumi Aksara.

Simatupang, H \& Purnama, D. (2019). Analisis Pelaksanaan Kurikulum 2013 Ditinjau dari Standar Proses Dalam Pembelajaran IPA Kelas VII SMP Al-Ulum Kota Medan. Jurnal Biolokus, 2(1) $135-138$.

http://dx.doi.org/10.30821/biolokus.v2i1.438

Stronge, J.H.; Ward, T.J., \& Grant, L. W. (2011). What Makes Good Teachers Good? Across-case Analysis of the Connection between Teacher Effectiveness and Student Achievement. Journal of Teacher Education, 62(4), 339-355.

Stronge, J.H.; Ward, T.J.; Tucker, P.D., \& Hindman, J. L. (2008). What is the Relationship between Teacher Quality and Student Achievement? An Exploratory Study. Journal of Personnel Evaluation in Education, 20(3), 165-184.

Sugiyono. (2016). Metode Penelitian Administrasi: Edisi Revisi. Bandung: Alfabeta.

Suwarna; Gufron, Anik; Sofyan, Herminarta; Munadi, Sudji;, Budiningsih, C. Asri; Haryanto; Soemarto, S. S. S. M. S. (2013). Modul Pelatihan Pengembangan Keterampilan Dasar Teknik Instruksional (PEKERTI). Yogyakarta: Universitas Negeri Yogyakarta.

Tuinamuana, K. (2011). Teacher professional standards, accountability, and ideology: Alternative discourses. Australian Journal of Teacher Education, 36(12), 72-82. https://doi.org/10.14221/ajte.2011v36n3.2

Vermunt, J. D. (2014). Teacher Learning and Professional Development. Teachers' Professional Development, 79-95. 
Ummi Nur Afinni Dwi Jayanti, Miza Nina Adlini \& Khairuna, Profil Keterampilan Menyusun Skenario Pembelajaran Mahasiswa Calon Guru Biologi Perguruan Tinggi Keagamaan

JURNAL BIOLOKUS Vol.3 (1)

Vidiarti, E., Zulhaini, Z., \& Andrizal, A. (2019). Analisis Kemampuan Guru Pendidikan Agama Islam Dalam Penyusunan Rencana Pelaksanaan Pembelajaran (Rpp) Kurikulum 2013. J-PAI: Jurnal Pendidikan Agama Islam, 5(2), 102-112. https://doi.org/10.18860/jpai.v5i2.5858

Wegner, C., Minnaert, L., \& Strehlke, F. (2013). The importance of learning strategies and how the project "Kolumbus-Kids" promotes them successfully. European Journal of Science and Mathematics Education, 1(3), 137-143. Retrieved from www.Kolumbus-Kids.de

Wulandari, E. (2019). Profil Kemampuan Menyusun Rencana Pelaksanaan Pembelajaran Saintifik oleh Calon Guru Matematika. Jurnal Pengembangan Pembelajaran Matematika (JPPM), I(2), 30-37.

Yousefkhani, M. (2008). Impact of Instructional Objectives on e/learning Materials. Proceedings of the World Congress on Engineering, 1. 